\title{
CHILDREN IN BESIKTAS DISTRICT OF ISTANBUL: THE TIME SPENT OUTSIDE ${ }^{1}$
}

\author{
Ahu PAKÖZ TÜRKELİ ${ }^{1}$ \\ Dr. Öğr. Üyesi, İstanbul Ticaret Üniversitesi, İnsan ve Toplum Bilimleri Fakültesi, Sosyoloji Bölümü ahupakoz@ gmail.com, ORCID: 0000-0003- \\ 0958-6063
}

Paköz Türkeli, Ahu. "Children in Besiktas District of Istanbul: The Time Spent Outside”. ulakbilge, 57 (2021 Şubat): s. $272-283$. doi: 10.7816/ulakbilge-09-57-09

\begin{abstract}
This paper aims to look at the factors affecting the time spend outside their homes for the preschool children aged 0-6 and their families in Istanbul metropole city center focusing on Besiktas district of Istanbul. Building new cities particularly with open areas and new facilities to encourage secure mobility and social interaction is a growing topic of discussion globally. The effects of environment on children and children's free movement in the natural environment on their mental and physical development are also another growing topic of discussion among the scholars worldwide. Using the methods of observation made in various spaces in Besiktas District such as market areas, streets and data from the face-to-face indepth interviews conducted with 24 parents of 0-6 aged children in Besiktas; the research aims to present the main factors affecting the children's interaction with the city, mainly the time spend outside together with their parents and alone. The paper will reveal that the number of people taking care of the child, the occupation of the parents, the age of the child, geography and facilities of the place lived, health problems and spacial closeness to the family relatives are prominent factors affecting the time spent outdoors for children. Related to the factors discussed in the paper the times spend outside with children and interaction with the city are mainly limited and not very qualified. The findings of the research can be of value for the further studies in the areas of sociology, education, architecture, and city planners.
\end{abstract}

Keywords: city children, time spent outside, child-friendliness, outdoor play, children daily life narratives

Makale Bilgisi:

Geliş: 11 Ocak 2021

Düzeltme: 18 Şubat 2021

Kabul: 20 Şubat 2021

(c) 2021 ulakbilge. Bu makale Creative Commons Attribution (CC BY-NC-ND) 4.0 lisansı ile yayımlanmaktadır.

\footnotetext{
${ }^{1}$ A shorter version of this article is presented in İstanbul Üniversitesi Edebiyat Fakültesi II. Uluslararası Sosyal Bilimler Kongresi (Congist’19), 18 Eylül 2019.
} 


\section{Introduction}

In the modern world 'the cities' are becoming the traditional human environment, in which human beings are born into, grow up, get educated, socialize, live and die. The UN report states 55\% of the world population, a billion of which is children (UN 2018 report), now lives in cities and it is projected that by 2050 that rate is expected to rise to $68 \%$. It is a well-known fact that the environment adds up a lot to who we are and as human beings, we also shape and transform the environment we live in reciprocally. In various studies the family, the relatives and people the child interacts with, the home children grow up, the schools attended, the neighborhood lived in and city and country they live in are all counted as the effective environment of the child (Atkins 1981; Beşpınar 2015; Bjornberg 1992; Chawla 1992; Chawla 2002a; Chawla 2002b; Craig 2006; Chaparro-Moreno et al 2019; Cushing 2016; Percy-Smith, Malone 2001; Ragan, McNulty 2004). Also the risks of the contemporary world and the costs of it for the families and children are also discussed in various sociological, architectural and ecological studies (Beck 1992, Beck et al 2013; Denney 2005). In this perspective, it can be argued that the cities people live in and grow up had a remarkable influence on the development of human beings' mind, attitudes, and perspective. Both for the adults and children the freedom and ability to access and explore the environment around them adds up a lot both to the child and the parents (Chawla 2002b; Chatterjee 2005; Çukur 2011; Daniel 1998). This research is designed to investigate the factors affecting time spent outdoors for the children aged between 0-6 in Besiktas District of Istanbul.

In the studies related to children and the city, scholars take the topic from a wide range of different aspects. Some emphasize the importance of physical and social environment in the healthy development of children. Especially for children in our research group aged 0-6, it is emphasized that the quality of the available social and physical environment is considerably important (Çukur, 2011; 70). Outdoors is open, changing environment with fresh air and sunlight, and being active outside contributes a lot to the children. Some architects like Herman Hertzberger (Herztberger, 2008) or Daniel Duke (Duke, 1998) argue also the architecture of the places they are educated and also grown up immensely add up to the learning environment and development of the child. Therefore, it can be argued the use of environment around and the places they spend their time in the city also had a great influence on the future lives of the children. Artificially created spaces like urban areas are affected by globalization and the natural areas within the cities are spoiled to a great extent throughout the years. The destruction and diminishment of natural areas caused mankind to be alienated from nature. According to various studies this decline of human's interaction with nature also intellectually, physically and spiritually affected people in a negative way (Taştepe et all, 2016). For older children especially it is argued that a "bedroom culture" has emerged both as a part of the "individualization" process and as an outcome of increasing concern for children's safety in a risk society (Livingstone, 2007). From this perspective many scholars argued the time spent outside in a natural environment is also important especially for the preschool children. According to experts for preschool children at least three hours should be spent outside home for healthy development of the child.

Plenty of research on children and positive environment interaction reveals that the children who had the chance to freely observe, discover, contact and interact with the natural environment had a better understanding of the world they live in (Wolfgang, 2004), and advancement of healthier physical, cognitive, fine and gross motor development (Seefeldt and Galper, 2007; Parker, 2008; Esach and Fried, 2005; Shin, 2008). Within this naturally oncoming process their abilities to research and analyze will also foster and they will try to find their own questions and answers. Recent studies on children and city vary from daily child experience to search for a better future and spread beyond the fields of sociology, psychology to varying fields such as architecture, urban studies, and ecological environment which examine practical children lives in the urban structure (Çukur, 2011). The effects of modern cities on children are studied by many scholars in various perspectives and this research aims to provide another important data for the researchers of this area. Istanbul is an important metropolitan city growing each day with its new residents and the position of 0-6 aged children in the city is also analyzed from various perspectives. In this paper, we will provide the data we got from our 2019 interviews conducted with the parents of children aged 0-6 in Besiktaş District of Istanbul. It mainly focuses on the factors influencing, enabling and disabling the children's time spent outdoors in this district.

\section{Method}

This research is mainly a qualitative field study, which also gets the help of the quantitative data using the methods of semi-structured and unstructured in-depth interviews made with 24 people and observation method in the 
district. The aim of the research is to reach the daily experiences and interactions of the families with the city by mainly focusing on families with children aged 0-6 and analyzing which factors affect the time spent outside and how often they go outside with their children. The interviews are conducted between April- August 2019 which is an advantageous period to catch the families outside enjoying the good weather and parks with their children.

The study is limited to the experiences of the people living and spending most of their time in the Besiktas district. Under the light of these, research questions of the study are:

- What affects the frequency and length of going out?

- How often in a day do the parents and their children use the public places, recreational areas, child parks and other places?

By observing the children and the areas they interact with and conducting face to face interviews with 24 parents from middle class families (upper and lower) living in the core center of Istanbul, Besiktas district, the research will analyze the factors affecting going out and how often the children/parents/caretakers use the city.

Being an insider of the group with a three year old child, and living in Besiktas for 11 years I also had the chance to compare my experiences with the interviewees and add up to the discussions and observations from a parent/resident perspective. In order to see the city from children's point of view, some playgrounds, kindergartens, recreational areas, different neighbourhoods in the district, market places and public areas are observed. Besiktas area is chosen because being in the core of the Metropolitan city Istanbul, the district constitutes a good example to look at the effects of urbanization on children living in the city center in Turkey. Living in the center of the city, and supposedly in an area well-connected to city's facilities, I believe these groups also represent a model for metropole city life in Turkey. When studying children's interaction with the cities and trying to get children's and parents' perspectives on a special topic (especially at this age group), I believe the most important part is the observation process. As a resident of Besiktas district for 11 years and a mother of a 3 year old child, I had the opportunity to observe the district carefully. The observation reveals us the unspoken or forgotten issues related to the topic.

The observations are made in the Besiktas district and the way the parents and children use the areas and period of time they spend in these areas are observed mainly. Besides, the observations made semi-structured in-depth interviews with 20 parents and unstructured interviews with 4 mothers in Besiktas district are conducted. The interviewees were reached through snowball technique. While choosing the interviewees the main focus was to reach the people who are both living and spending a great part of their free time in Besiktas district and who are residents of the area for more than 5 years.

The interviews lasted about one and a half hour and topics discussed mainly included a wider area of research for further studies, questions about their daily/weekly routine and habits. Although this research discusses families with children in Besiktas; I limit the case with 24 middle class families' mothers in Besiktas. The aim was to reach the medium families living in the cities, and in this case Besiktas area. Therefore, I tried to reach middle class families of both lower-middle class and upper-middle classes and with this aim reached housewives, working mothers, and nonworking mothers who gave up their job after giving birth ${ }^{2}$ and local shop owners working with their husbands and a lone.

In order to get an overall report about the interviews; the interviewees were aged between 24- 48 years old. In the semi -structured in depth interviews made with 20 mothers, 5 mothers interviewed were local shop owners. I also had the chance to make unstructured interviews with some of their husbands. 4 of them were housewives with previous work experience. They all choose to give up their job after the child is born. 12 of them were working mothers. Most of the fathers were full time working fathers and mostly not at home during the office hours (8.00-17.30) except 4 fathers; one of them musician and have irregular working hours, 2 of them computer engineer and could work from home time to time and one of them naval officer and goes to work away from home generally for 6 months. 9 of the children are going to nursery/kindergarten or primary schools and others are not attending any schools or daycare centers but cared at home in general. 18 mothers interviewed were university graduates (public/private), 2 of them are high school graduates.

\footnotetext{
${ }^{2}$ This is also an important topic to emphasize that some of the mothers decided to leave their job after giving birth. The topic of this study is not gender studies yet nearly all of the interviewees are mothers and when studying family and children it attracts attention that most of the burden is still on women. It seems very hard and challenging for women to do both; raise their children and continue their job with productivity.
} 
Table 1. Information about Interviewee Parents

\begin{tabular}{|c|c|c|c|c|c|c|c|c|}
\hline Number & $\begin{array}{l}\text { Interviewee } \\
\text { Job/Age }\end{array}$ & $\begin{array}{l}\text { Who is } \\
\text { interviewed? }\end{array}$ & $\begin{array}{l}\text { Which } \\
\text { neighbourhood } \\
\text { they live in }\end{array}$ & $\begin{array}{l}\text { How many } \\
\text { children they } \\
\text { have/gender? }\end{array}$ & $\begin{array}{c}\text { Mom still } \\
\text { Working/Or } \\
\text { Not }\end{array}$ & Dad's job & $\begin{array}{l}\text { How many } \\
\text { hours does } \\
\text { the child } \\
\text { go out }\end{array}$ & $\begin{array}{l}\text { Who is taking care } \\
\text { of the child during } \\
\text { the day most? }\end{array}$ \\
\hline 1 & $\begin{array}{l}\text { Academician/39 } \\
\text { years old }\end{array}$ & Mother & Türkali & 4 year old/ boy & $\begin{array}{l}\text { Working } \\
\text { Mom }\end{array}$ & $\begin{array}{l}\text { Architect in } \\
\text { Private Sector }\end{array}$ & 1 hour & Grandmother \\
\hline 2 & $\begin{array}{l}\text { Academician/45 } \\
\text { years old }\end{array}$ & Mother & Ulus & $\begin{array}{l}3 \text { children aged } \\
6-9-12 / \text { all boy }\end{array}$ & $\begin{array}{l}\text { Working } \\
\text { mom }\end{array}$ & $\begin{array}{l}\text { Senior manager } \\
\text { in private sector }\end{array}$ & 1 hour & $\begin{array}{l}\text { Grandmother/ } \\
\text { Mother/House } \\
\text { Assistant }\end{array}$ \\
\hline 4 & Housewife/24 & $\begin{array}{l}\text { Mother/ } \\
\text { Father/ } \\
\text { Babysitter }\end{array}$ & Ulus & 4 year Old /Girl & Not Working & Businessperson & 3 hours & Babysitter/ Mother \\
\hline 5 & $\begin{array}{l}\text { Studied } \\
\text { International } \\
\text { Relations /40 } \\
\end{array}$ & $\begin{array}{l}\text { Mother/ } \\
\text { Babysitter }\end{array}$ & Ulus & $\begin{array}{l}\text { 6-9 year old } \\
\text { /girl and boy }\end{array}$ & Not Working & Businessperson & 3-4 hours & $\begin{array}{l}\text { Babysitter/ } \\
\text { grandmother/mother }\end{array}$ \\
\hline 6 & $\begin{array}{l}\text { Pharmacist/ } 37 \\
\text { years old }\end{array}$ & Mother & Şair Nedim & $\begin{array}{l}3 \quad \text { Year Old } \\
\text { Child/ Boy }\end{array}$ & $\begin{array}{l}\text { Not Working/ } \\
\text { Plans to work } \\
\text { a year later }\end{array}$ & $\begin{array}{l}\text { Engineer in } \\
\text { Private Sector }\end{array}$ & $\begin{array}{lr}\begin{array}{lr}\text { Half } \\
\text { hour- } \\
\text { hour }\end{array} & 1 \\
\end{array}$ & Mother \\
\hline 7 & $\begin{array}{l}\text { Computer } \\
\text { Engineer/ } \\
\text { years old }\end{array}$ & $\begin{array}{l}\text { Mother and } \\
\text { Father }\end{array}$ & Abbasağa & 3 Year Old/Girl & $\begin{array}{l}\text { Mom started } \\
\text { working after } \\
6 \text { months of } \\
\text { giving birth }\end{array}$ & $\begin{array}{l}\text { Computer } \\
\text { Engineer in } \\
\text { Private Sector }\end{array}$ & $1-2$ hours & $\begin{array}{l}\text { Grandmother/ } \\
\text { Mother }\end{array}$ \\
\hline 8 & $\begin{array}{l}\text { Computer } \\
\text { Engineer/ } 35 \\
\end{array}$ & $\begin{array}{l}\text { Mother and } \\
\text { Father }\end{array}$ & Bebek & $\begin{array}{l}\text { Year Old/ } \\
\text { Girl }\end{array}$ & $\begin{array}{l}\text { Mother not } \\
\text { Working }\end{array}$ & $\begin{array}{l}\text { Engineer in } \\
\text { Private Sector }\end{array}$ & 2 Hours & $\begin{array}{l}\text { Grandmother/ } \\
\text { Grandfather }\end{array}$ \\
\hline 9 & Media Executive & Mother & Şair Nedim & $\begin{array}{l}\text { Year Old/ } \\
\text { Boy }\end{array}$ & $\begin{array}{l}\text { Working } \\
\text { from Home }\end{array}$ & Manager & 4 Hours & Mother and Father \\
\hline 10 & Private Sector $/ 35$ & Mother & Balmumcu & 5 Year old/girl & Not Working & $\begin{array}{l}\text { Senior Manager } \\
\text { in private sector }\end{array}$ & 1 Hour & Alone \\
\hline 11 & $\begin{array}{ll}\text { Local } & \text { Shop } \\
\text { Owner/43 } & \\
\end{array}$ & Mother & Türkali & 4 Year Old/Girl & Working & Accountant & 4-5 Hours & $\begin{array}{l}\text { Grandmother/ } \\
\text { Grandfather }\end{array}$ \\
\hline 12 & $\begin{array}{l}\text { Local Shop } \\
\text { Owner/42 }\end{array}$ & Mother & Muradiye & 5 year Old/Boy & Working & $\begin{array}{l}\text { Local Shop } \\
\text { Owner helping } \\
\text { wife }\end{array}$ & 3 Hours & $\begin{array}{l}\text { Grandmother/ } \\
\text { Grandfather }\end{array}$ \\
\hline 13 & $\begin{array}{ll}\text { Local } & \text { Shop } \\
\text { Owner/47 } & \end{array}$ & $\begin{array}{l}\text { Mother and } \\
\text { Father }\end{array}$ & Cihannuma & $\begin{array}{l}5-6-9 \quad \text { Years } \\
\text { Old/All boy }\end{array}$ & $\begin{array}{l}\text { Not Working } \\
\text { Helping } \\
\text { Husband }\end{array}$ & $\begin{array}{l}\text { Local } \quad \text { Shop } \\
\text { Owner }\end{array}$ & 3 Hours & Mother \\
\hline 14 & $\begin{array}{l}\text { Local Shop } \\
\text { Owner/35 }\end{array}$ & Mother & Dikilitaş & 3 Years Old & $\begin{array}{l}\text { Working with } \\
\text { Husband }\end{array}$ & $\begin{array}{l}\text { Local Shop } \\
\text { Owner }\end{array}$ & 3-4 Hours & $\begin{array}{l}\text { Grandmother/ } \\
\text { Grandfather }\end{array}$ \\
\hline 15 & $\begin{array}{l}\text { Local Shop } \\
\text { Owner }\end{array}$ & $\begin{array}{l}\text { Mother and } \\
\text { father }\end{array}$ & Ortaköy & 5 year old & Working & $\begin{array}{l}\text { Working with } \\
\text { wife }\end{array}$ & 2 Hours & $\begin{array}{l}\text { Mother / } \\
\text { Kindergarten }\end{array}$ \\
\hline 16 & Musician & Father/35 & Şair Nedim & 6 Years Old & Working & $\begin{array}{l}\text { Working mom in } \\
\text { private sector/ } 30 \\
\text { years old }\end{array}$ & 1 Hour & $\begin{array}{l}\text { Mother/ } \\
\text { Grandmother } \\
\text { recently }\end{array}$ \\
\hline 17 & Housewife & Mother/35 & Y1ldız & 2,5 Years Old & Not Working & $\begin{array}{l}\text { Manager in } \\
\text { private sector }\end{array}$ & 1 Hour & Mother \\
\hline 18 & $\begin{array}{l}\text { Manager in a } \\
\text { Hotel/41 }\end{array}$ & Mother/41 & Gayrettepe & 4 Years Old & Working & Director of Sales & 2 Hours & $\begin{array}{l}\text { Grandmother/ } \\
\text { Grandfather }\end{array}$ \\
\hline 19 & Sales officer/39 & Mother & Ortaköy & $\begin{array}{l}2 \text { Years Old/ } \\
\text { Girl }\end{array}$ & Not Working & Security staff & $\begin{array}{l}\text { Half an } \\
\text { Hour/ } \\
1 \text { Hour } \\
\end{array}$ & Mother \\
\hline 20 & Housewife/30 & Mother & Ortaköy & 2 Years Old & Not Working & Naval officer & 1 Hour & Mother \\
\hline 21 & Housewife/34 & Mother & Fulya & $\begin{array}{l}\text { Twins } 3 \text { Years } \\
\text { Old /Girl }\end{array}$ & Not working & Private sector & 0-1 Hour & Mother \\
\hline 22 & $\begin{array}{l}\text { Expert in a } \\
\text { Bank/Mother } 38\end{array}$ & $\begin{array}{l}\text { Mother and } \\
\text { Father/36 }\end{array}$ & Gayrettepe & 1 Year Old Boy & $\begin{array}{l}\text { Working } \\
\text { after } 6 \\
\text { months } \\
\end{array}$ & $\begin{array}{l}\text { Manager in a } \\
\text { Bank }\end{array}$ & 1 Hour & Grandmother \\
\hline 23 & Housewife & Mother/24 & Ortaköy & 3 Year Old Boy & $\begin{array}{l}\text { Just started } \\
\text { working }\end{array}$ & Divorced & $0-1$ hour & $\begin{array}{l}\text { Mother alone } \\
\text { /Kindergarten }\end{array}$ \\
\hline 24 & Housewife & Mother/24 & Ortaköy & 3 Year Old Boy & Not working & Private Sector & 1 hour & $\begin{array}{l}\text { Mother } \\
\text { alone/kindergarten }\end{array}$ \\
\hline
\end{tabular}

Seven people interviewed stated their mothers/mother-in-laws also reside in Besiktas. One of them, whom I later made an unstructured interview with, is a single mother who recently moved to Sisli district two months ago from Ortaköy, Besiktas therefore I included her in the research. In August of 2019 her only 3 year old child started nursery school in Balmumcu, Besiktas. She stated her ex-husband also lives and works in Besiktas therefore they spend most of their time in Besiktas area. She is looking after her 3 year old child alone. She stated up to now she was not working for the last 4 years in order to take care of the 3 year old boy although she is a university graduate and had previous work 
experience. It was her first working day when we interviewed her so I have included her as a housewife in the table as I have listened about her previous experiences as a housewife.

All of the 5 local shop owners' children were mostly cared by their grandmothers/grandfathers together. One stated her daughter is also going to a private kindergarten. Apart from them all of the mothers spoken stated they did not work and care for their children until the child is at least 6 months old and mostly 8 months old and after that month differences occur mostly related to the occupational group and financial situation of the families. One of the housewives who has twins aged 3 stated she had been taking care of the babies mostly by herself. At the age of three the twins started nursery school. She evaluated the hardships of looking after twins and stated from time to time she took help from a cleaning lady for the housework such as cleaning or cooking. She stated sometimes the mother of her husband also comes to help her but that visits were not regular and mostly the kids are taken care of by herself. According to the answers obtained from the interviews and observations made in the region, an overall analysis of the study and the findings will be discussed below in the discussion part and findings part.

\section{Characteristics of the District: Besiktas and General Discussions}

Besiktas area is at the core of Istanbul city at the European side. It is one of the oldest residential areas in Istanbul composed of coastal and inland settlement areas. It is strategically in a very important position as it links the coast to the interior roads and has a link to the bridges of Bosphorus and ferries which connect the Asian side to the European side. That is why although it is one of the less populated areas in Istanbul its population reaches approximately 2 million every day with the tourists, visitors and pass-byers. (source: http://en.besiktas.bel.tr/category/newcomers-guide/) Therefore, the residents of the area can feel this congestion and crowd in their daily routines. This is another reason I choose it as the case area because of its highly changing population and mobility and enormous diversity. I believe it can be a good representative sample for the model city life for Turkey. When babies and children are topic of discussion hectic, crowded places are not mostly very favorable, but Besiktas is still very popular for the families with children. According to TÜíK data 181.074 people live in Besiktas and 75.985 people $41,96 \%$ of the whole are married. (Table 2)

Table 2. Besiktas Marital Status

\begin{tabular}{lllll}
\hline & Married & Single & Divorced & Widowed \\
\hline Number of People & 75,985 & 48,758 & 14,248 & 10,063
\end{tabular}

Of course, all of the married people do not have children, or each person who has children is not married but the age distribution in (Table 3) also shows us that children population is at a substantial amount. Most of the people interviewed stated that they choose the area because of its location; namely its easier and versatile ways of connection to the other areas and Asian side. Some choose to live there because it is their family house or they want to live close to their parents.

Tablo 3. Besiktas Age Distribution

\begin{tabular}{|c|c|c|c|c|c|c|c|c|c|c|c|c|c|c|}
\hline Age & $0-4$ & $5-9$ & $10-14$ & $15-19$ & $20-24$ & $25-29$ & $30-34$ & $35-39$ & $40-44$ & $45-49$ & $50-54$ & $55-59$ & $60-64$ & $65+$ \\
\hline $\begin{array}{c}\text { Number of } \\
\text { People }\end{array}$ & 7,461 & 7,504 & 8,129 & 8,528 & 12,704 & 14,009 & 15,744 & 17,265 & 15,858 & 14,092 & 12,021 & 10,817 & 9,588 & 27,354 \\
\hline
\end{tabular}

All of the parents are conscious about the time spent outside and stated they are trying to go out every day with their child. However, interviews and observations reveal that in Besiktas sometimes the children stay at home all day on weekdays and could only go out during the weekends. Whenever they could go out with the kids, the parents' first choice is mostly going to the nearest park or recreational area to their home and spending around an hour - an hour and a half with the child there.

When mother and father both are working all day the child may not go outside during the weekdays, at the weekends the families try to spend more time outside. At the weekends, the first choice is again the parks and seaside areas but this time the family sometimes chooses to spend some time outside the Besiktas area which is mostly depicted as "hectic and crowded".

When we compare the time spent outside with children, 5 local shop owners' children are among the ones who spend more time outside. One mother even stated her 4 year old daughter goes out to the playground next to their house 
with her grandparents in the morning right after breakfast for two hours and in the afternoon after naps for two more hours. She also added sometimes, when she goes home around 19:00-20.00 she takes the child again outside with her husband for an hour or so.

Secondly, mothers who are housewives and look after their children with the help of someone (grandparent/babysitter) can spend more time outside with their children. Moreover, the children living in residential complexes with segregated private gardens are also among advantageous ones spending more time outside. Their parents stated they can also play with short term intervals during the coffee times of their mothers with the neighbors and sometimes at the weekends when all the neighbors are doing picnic or barbeques as well as the daily one-two hours play time in the garden. The ones who spend less time outside are the working mothers' children taken care of by only grandmothers or baby sitters and housewife mothers looking after their children alone. One working mother who did not work until the child was 8 months old stated her husband was working full time as a manager of a company and there were weeks she could not take the child for even a walk outside. She argued all the housework, taking care of the child at home alone and the geography of the Besiktas area mostly kept her inside the house. These general discussions will be categorized and evaluated more in detail in the interviews and findings part to reveal the factors affecting the children's time spent outside.

\section{Findings ans Interviews}

The spaces the children spend most of their time has a great role in the physical development and social behaviors of the children (Topgül and Elibol, 2019: 121). A lot of scholars pointed the importance of free time spend outside during childhood for the healthy mental, social, physical, emotional development of the children.

Malone (2007, p. 9) discusses the formation of "child-environment identities" that develop when children use and move through places and spaces in a city. These identities have physical, social, natural and learning dimensions. The interplay between them, although dynamic, is ideally integrated such that children and young people develop as functional, confident and competent "environmental users" in their present and future lives. (Wilks, 2010: 28).

Being part of the social world around them is a big part of being human. There are a lot of risks in healthy development of children and families when they are excluded from the natural and sociological environment. Contemporary societies are also defined as a risk society in terms of the environmental and various other problems of the society arising as a result of high urbanization and industrialization (Beck, 1992).

When their daily/weekly schedule is examined, it is clearly seen that all the parents and care-givers we interviewed are making an effort to spend time outside and conscious about the importance of being outside with their kids. All of the interviewees pointed to the importance of being outside and their wish to spend more time outside home. They also mentioned the babies are happier and quieter whenever they spend some time in nature. Up to 1 year old according to the interviews the time spend outside with the child is less than the later ages. In the following section, rather than going on the interview questions one by one I would like to summarize the most repeated topics under some headings and subtitles. These titles and answers given will be chosen according to their effect on the time spend outside.

\section{What Criterions Effect the Time Spent Outside?}

a. People Taking Care of the Child:

According to the interviews and my observations in the region the time spent outside the house with children varies first of all according to the people caring for the child a lot. At this point 3 different groups emerge;

1. Children nurtured by grandparents mostly grandmothers,

2. Children taken care of by their parents mostly mothers and

3. Children looked after by their babysitters/nannies.

Another two groups under these three are;

The children with working-moms and children whose mothers either gave up working after giving birth or whose mothers are housewives; these groups had differences in the period of time spend outside with their children.

In the first two groups, when grandparents or parents are caring for the child all day long, the child can spend more time outside enjoying various parks and recreational areas. According to the daily needs of the family, the child is taken with them all around the city and they can go shopping, go to cafes or restaurants or parks around the area with the child. At this point, it turns out another important factor is the number of the family members caring for the child. 
The more people are taking care of the child the more time can be spent outside with the child. It also increases the variety of places visited outside home. It also turns out if the grandparents are alive, and the mom is working, they are mostly in charge of taking care of the child during the day even when the child has a babysitter.

When only one member is caring for the child, (mostly the mother) then again the variety of places visited decreases as either this person also takes care of the house or cannot handle the child alone in the streets or shopping areas for a long time. When a mother of twins living in Besiktas-Yildiz area and taking care of the children alone was asked how she travelled around the city before the children learnt to walk; she replied as "I mostly choose not to go anywhere alone" (mother 34 years old, housewife). She stated when the children turned 4 months old she hired a person to help her in the house work such as cleaning and cooking for two days a week. However, she was the only person taking care of the two children. She stated that the landscape of Besiktas and the situation of the pedestrian roads are the main reason she cannot travel around with her children. She pointed out that it is impossible to walk around continuously with a twin baby stroller in Besiktas. All mothers who are taking care of the baby alone pointed out that they wanted to go out with their babies as they were also bored being at home alone. Yet, according to the mothers' answers, it was impossible mostly because of all the housework, difficulty of time and work management alone, and geography of the neighborhood and the inadequate infrastructure of the pavements. Then, they generally choose going out mostly at the weekends or at night together with their husband.

When the grandparents are taking care of the children together and the grandfather helps the grandmother, according to the interviews and my observations the child's interaction with the city increases. As two people, they can easily cope with these problems mentioned above. They can carry the stroller or the child whenever there is an obstacle in the road. If only grandmother is looking after the child the previous problems for a single person is similar for them and sometimes even harder for them to go out alone as it also becomes taking responsibility for the child alone.

In the third group, children who are cared for nannies face similar problems as mentioned above and sometimes the child can stay at home all day long. In this case, the child either goes out with the parents after 17.00-18.00 when parents come back from their job or the worst case (when the parents come home late or tired) only during the weekend. Therefore, no matter who cares for the child, actually the number of people who can help matters crucially when looking at the time spent outside. Taking the child outside is a great responsibility as in this age group, the person caring for the child also needs to carry child's stuff with him/her. Moreover, for 0-2 years olds you also need to either carry the child or the stroller with you. Therefore, as the number of people around the child increases the child can be taken outside more.

\section{b. Occupation and availability of the husband:}

The first element also brings us to the second one. "When more people are taking care of the child the child can stay outside more". This is also true for the father of the child. If he is available during the daytime or after work, he can help more to his wife more. This makes it easier to stroll around the city center as well.

Among the parents spoken the ones who could go out less were the child of a navy officer whose mother was taking care of the baby alone. She stated her husband was going on duty for 6 months and she and her daughter could only travel around the lodging area they live in. So, the variety of the places seen outside also diminish together with the time spent outside when the number of the people caring for the child is only one person most of the day.

The twins were the second group to go out less with the mother whose husband is a musician. The musician is working as a music teacher from 09.00-18.00 working days and at the weekends working as a musician (guitarist) at the professional concerts. Thus, he is mostly absent from home. His wife who was not working until last year was taking care of the child alone and sometimes getting little help from her mother-in-law. After turning 4 years old their child started going out more but before she could only take her outside once every two-three days. Mothers stated most of the time they are home alone with the babies and they cannot handle all the work like cooking, nursing, feeding, sleeping, bathing the baby and cleaning the clothes and home and besides going outside. It seems impossible for them. Therefore, also for these reasons they can not take the child outside.

c. The age of the child:

When the child is older than 2 years old, mostly the mobility with the child increases as the workload like nursing, sleeping and feeding the baby can take less time. Moreover, also after that the child starts walking and the condition of the roads, streets and hilly areas can arouse fewer problems. However, a mother of a 2 year old complained the feeding time can also take more time than before and takes around 5 hours each day which leaves a little time to spend outside. When they are alone they also do not want the child to eat outside (like as a picnic) as they cannot 
handle the bags full of meal, child's needs like diaper, extra-clothes, child and toys all at the same time alone. These factors all have an impact on the time spent outside with the child. As a result of all these the child is mostly kept at home when only one parent is taking care of the child.

However, despite these problems in the interviews, especially after two years old whoever is taking care of the child, they try to be outside with the child at least 45 minutes or an hour every day. Mostly chosen areas are the playgrounds which are closest to the interviewees' house. Sometimes, the small gardens the houses have can be a solution for the parents if the apartment, single family home they live in has an even very small garden. They generally bought small sand pools or inflatable water pools, or small swings or slides to entertain their children in their garden. This is also discussed in a different heading below.

\section{d. Geography of the area}

Some still argue baby strollers are not a very easy way of travelling in the city center and cause them to eliminate some areas from their daily routine map. For instance, entering the Besiktas Cars1 area (market area) where it is very hard to move with a stroller and is always very crowded with people is mostly excluded by the families from their daily map. Some stated they usually go to the market area with a baby carrier. However it is also not easy to climb the roads or go down the road with a soft carrier and diaper bag.

This is a common response I got from each parent I interviewed caring for a child younger than 4 years old. The hilly areas and ground, unstable and wobbly cobblestones, the situation of roads and pavements, and the cars parking on the pavements or forbidden areas, make it harder for a single person (even sometimes for two people) to use baby strollers in the area. Another annoying factor according to the parents is the suddenly narrowing pavements, the trees or poles and sign plates in the middle of the pavements which are also controversial issues in most of the cities in Turkey. They make it even harder to move with a stroller.

\section{e. The facilities around the house}

Together with the interviews my experiences in the field shows that narrow and irregularly organized pavements and hilly roads make it harder for a person with a child to move around frequently. The people who live next to a playground or whose house is in a flat area stated they go outside more with their children. However, again it seems the children are mostly kept in their own neighborhoods especially during the weekdays.

The environment is defined as all external forces and factors to which an organism or aggregate of organisms is actually or potentially responsive. The environment is important for human beings in that it determines the way human action is done, and as a result, functions as a determinant of the quality of human life (Jeong, 1997: 2). Children deprived from the environment and not introduced to the new places and different environments than their own could later have problems in their development of relationships, attitude, behavior, or personality. Therefore, accessing the nature and city amenities can be counted as an important factor of the quality of life.

In an area highly connected to the city life, it is seen that these families are deprived of reaching nature and market areas frequently with their child, and when a lone it is nearly impossible as a result of the defective roads and above discussed topics. When the families live in residential complexes with parks and playgrounds isolated from the others who are not living there, according to the responses the children and families can spend more time outside when they live in this kind of residential areas. The condition of the roads such as damaged, incomplete, broken, inaccessible, sometimes blocked or very narrow sidewalks also make it harder for a person with a child to move around frequently or for a long time. Even when you observe someone with a baby stroller in the street you can observe it is impossible for him/her to walk alone without any help from someone to continue her/his journey uninterruptedly on the sidewalk. Therefore, the quality of the roads and the place the house is located can be an important topic of discussion when someone with a baby wants to go out in Besiktas district. Some live in small homes with no balconies or terraces to spend some time in the open air while children are at home. Some people interviewed stated they have a small balcony and when the child is not taken outside they try to spend some time there with the child especially when the weather is good. Therefore, balconies also appear as an important feature for the families with children.

Two people I interviewed were living in apartment complexes with special playgrounds and gardens. In that case, it is seen that the children spend most of their outdoors time in these complexes. One parent who has 3 children stated "we moved to this house for the children. It was a nightmare walking around Besiktas with our children. Now, I can drink tea or speak to my friends while the children are playing with the neighbors' children or alone by themselves." These apartment complexes are booming in the last 10 years and preferred by the families for varying reasons; however, children stand out as the most important factor among them while choosing these residential areas. 
Nevertheless, in this case the diversity of the people and places diminish. Spending most of their time in these complexes and in their facilities and gardens with the people like themselves these children are to a great extent taken away from the real world and confined in their "secure" area.

\section{f. The Workload of the Jobs}

As another factor, the answers show the workload the parents have at work are also effective at home. When the parents are too tired working in their offices or jobs, or when they have to finish some of the work at home this also affects the relationship with the babies and children. In our case, when they return home they do not want to go out again or continue their work from home. The ones who have a baby sitter at home are luckier as they can divide the workload and one person at home can take the child for a walk or to play outside.

\section{g. Health Problems}

One of the last factors recurrently counted among the effective factors in going outside is sicknesses (when someone at home is ill). Especially during the fall and winter periods, the children can catch cold or other sickness very frequently. This becomes an effective factor for mothers not going outside with children. Moreover, all the parents taking care of the child stated they also mostly got sick frequently in the first year the baby was born. Lack of sleep and being tired all the time are thought as the main reasons of sickness.

\section{h. Closeness to the Relatives and Close Friends}

The last item, closeness to the relatives again brings us closer to the triad scheme I made earlier: when there is assistance nearby and the child is not taken care of alone the time spent outside increases. The relatives living close by can be a great help according to the interviews made. Even the urge to go there to meet with the people you know and the knowledge that the child will spend some time with others for a time being increases the preference to go out. "When the relatives live close by and you can go there within 5-10 minute walk it is not a torture to travel with children" (mother of 3 year old, age 37). When they reach their house the child can also play with the adults and other children if there are any present. They can also visit the family and asist the parents to go out together with their children. These kinds of examples are mostly seen in Yildiz Park, where families with children have picnic together with their relatives living close by. At the weekends they meet there in the morning to have breakfast together and the kids can spend some time in the forestry area.

\section{Conclusion}

In this paper, the factors affecting the children's time spent outside and duration the children living in Beşiktaş district of Istanbul can spend time outside are examined with reference to the indepth interviews conducted with the parents and caregivers and observations made in the field. In order to summarize the results with reference to the semistructured interviews conducted with 20 people in Besiktas and 4 unstructured interviews (24 interviews in total) and observations made in the area; the answers to the question "What affects the time spent outside in the city?" can be summarized as this:

The time spent in the city first of all, greatly depends on the people and number of people looking after the baby. This group is divided into three; grandparents (grandmother/grandfather or together), babies' mother/father (together) or the babysitter. As it came out the more people are taking care of the baby the more time the baby can spend outside home and the more variety of places they can visit. For instance, when grandparents are looking after the baby together or the baby is taken care of by both mother and the grandma during the daytime the duties are distributed and the child can be taken outside and can be taken to various places within a week.

Secondly, related to the first factor, the occupation of the parents especially the father's job can influence the the amonth of time the baby spends outside. When the father is more available and more around to help and assist the baby and mother, the child can be taken outside more. The workloads of parents in their jobs and the nature of the job they do can also be counted under this heading as well. When the parents come home tired or bring their work home it also decreases both the time spent with the kid together with the chances of going outside.

Thirdly, the time spent outside also depends on the place they are living. Both the geography of the area and facilities around the house are effective factors providing or hindering the child to be outside more. The apartments with large gardens and playgrounds make it easier for the little residents to go outside and spend more time outdoors. However, this time the variety of people and areas the children faces diminishes. At this point the geography of the area (hilly/not hilly) and the condition of the pavements and roads can also be effective for the parents with little children. 
Fourthly, the age and health problems of the child can be counted as another factor for the child to be able to go outside and how parents help them to be more mobile and active during the day. When the child gets older some of the workloads diminish and the parents can be more active outside with the kids. The health problems can be another important element hindering both the child and the parents to go outside especially during fall and winter.

Last factor emphasized in the interviews was the living close to the relatives or close friends that can assist the mother and father when they are outside with the baby. Even the thought that they can come and help anytime, seems to be comforting for the parents and increases the urge for going outside.

As a final word for the interviews conducted and my observations made in the area, it can be argued that the children aged 0-6 cannot become completely active agents and interact with the city actively in Besiktas district due to the explained factors. The results of the study are in line with the previous researches showing the decrease of the physical activity in the metropol cities (Booth, 2000; Centers for Disease Control and Prevention, 2002; Reilly et al., 2004; Tomkinson et al., 2003) Urbanization and population growth can change the lifestyle of the inhabitants of the area (Coşkun 2020: 62). On the positive side, the schools are generally aware of this decrease in the physical activity and try to include gymnastics, physical education, dances and outdoor plays to their school schedules to keep the children active during the daytime. Some of them include regular visits to Yildiz Park in order to increase children's interaction with nature. These are all positive developments made by kindergartens and day cares. However, not every parent is sending their children to kindergarten. The 0-6 year old children are to a large extent together with their parents and families during the day. In order to increase the children's physical activities and interaction with the city, the city they live in should be suitable for their daily routine and should provide them with new opportunities to foster. In the interviews there are of course various suggestions for a better environment yet I believe the best is to design the places or change them together with children and parents in order to make them more accessible, convenient and useful for children. The local administrations need to build more participatory and inclusive grounds to reach more children and announce the developments achieved by the municipalities frequently to the families with children.

\section{References}

Atkins, Richard, N. "Finding One's Father: The Mother's Contribution to Early Father Representations." Journal of the American Academy of Psychoanalysis 9.(1981): 539-559.

Beck, U. Risk Society: Towards a New Modernity. trans, by M. A. Ritter. London: Sage Publication, 1992.

Beck U, Blok A, Tyfield D, Zhang Jy. "Cosmopolitan Communities of Climate Risk: Conceptual and Empirical Suggestions for a New research Agenda." (2013): 1-21.

Bento, G. G. Dias."The Importance of Outdoor Play for Young Children's Healthy Development." Porto Biomed. Journal (2017/5): 157-160.

Beşpınar, F. U. "Between Ideals and Enactments: The Experience of 'New Fatherhood' among Middleclass Men in Turkey”. Gender and Sexuality in Muslim Cultures. In Gül Özyeğin (ed.). Ashgate Publishing, Ltd. 2015: 95114.

Bjornberg, U. "Parenting in Transition", European Parents in the 1990s. In U. Bjornberg (ed.). New Brunswick: Transaction Publishers. (1992): 83-103.

Booth, M., "What Proportion of Australian Children are Sufficiently Active?" Medical Journal of Australia 173. (Suppl.7), (2000): 6-7.

Centers for Disease Control and Prevention, "Physical activity levels among children aged 9-13 years United States", Morbidity and Mortality Weekly Report 52/33 (2002): 785-788.

Chawla, L. "Childhood Place Attachments". In A. Altman and S.M. Low (eds). Place Attachment. Vol. 12. New York: Plenum, 1992.

Chawla, L. "Evaluating Children's Participation: Seeking Areas of Consensus", PLA Notes, 42, (2001): 9-13.

Chawla, L. "Insight, Creativity and Thoughts on the Environment: Integrating Children and Youth into Human Settlement Development", Environment and Urbanization, 14(2), (2002a): 11-22.

Chawla, L. Growing Up in an Urbanising World. Michigan: Unesco Publishing Earthscan. 2002b.

Chaparro-Moreno LJ, Justice LM, Logan JAR, Purtell KM, Lin T-J. “The Preschool Classroom Linguistic 
Environment: Children's Firstperson Experiences”. PLoS ONE 14(8) (2019). e0220227. https://doi.org/10.1371/journal.pone.0220227

Chatterjee, Sudeshna. "Children's Friendship with Place: A Conceptual Inquiry.” Children, Youth and Environments 15/1 (2005): 1-26.

Craig, Lyn. "Does Father Care Mean Fathers Share? A Comparison of How Mothers and Fathers Intact Families Spend Time with Children". Gender \& Society, 20 (2006): 259-281.

Cushing, D. F. "Youth Master Plans as Potential Roadmaps to Creating Child- and Youth-friendly Cities". Planning Practice \& Research, 31/2 (2016): 154-173.

Çukur, D. “Okulöncesi Çocukluk Döneminde Sağlıklı Gelişimi Destekleyici Dış Mekan Tasarımı”. Süleyman Demirel Üniversitesi Orman Fakültesi Dergisi, 12(2011): 70-76.

Coşkun, Ç. "Modernization and Social Change: Social Structure in Kılavuzlar Village.” Turkish Studies- Social, 15(7), (2020): 53-65. https://dx.doi.org/10.47356/TurkishStudies.47135

Daniel D., Does It Matter Where Our Children Learn? University of Virginia Press: Virginia, 1998.

Denney D. Risk and Society. SAGE Publications Ltd, 2005.

Eshach, H. And Fried, M. N. "Should Science be Taught in Early Childhood?". Journal of Science Education and Technology, 14 (2005): 315-336.

Herztberger, Herman, Space and Learning, 010 Publishers: Rotterdam, 2008.

Jeong, D.Y. “A Sociological Implication of Environment in Social Development." Korea Journal of Population and Development, Vol. 26, No. 2 (December 1997): 1-13.

Livingstone, S. "From Family Television to Bedroom Culture: Young People's Media at Home", in E. Devereux ed. Media Studies: Key Issues and Debates, London: Sage Publications, 2007.

Parker, C. "The Outdoor Learning Environment." In D. Whitebread \& P. Coltman Eds. Teaching and Learning in the Early Years. Third Edition. New York: Routledge, 2008.

Percy-Smith, B. \& Malone, K. "Making Children's Participation in Neighborhood Settings Relevant to the Everyday Lives of Young People”, PLA Notes, 42, (2001):18-22.

Reilly, J.J., Jackson, D., Montgomery, C., Kelly, L., Slater, S., Grant, S., Paton, J., "Total Energy Expenditure and Physical Activity in Young Scottish Children: Mixed Longitudinal Study.” Lancet 363 (9404), (2004): 211 212.

Shin, K. H. Development of Environmental Education in the Korean Kindergarten Context. (Unpublished Doctoral Dissertation), University of Victoria, Canada, 2008.

Seefeldt, C. And Galper, A. Active Experiences for Active Children: Science. Second Edition. New Jersey: Pearson, 2007.

Taştepe T., A. Başbay M., Yazıcı Z. "Kent Merkezlerindeki Ekolojik Temelli Oyun Alanlarının Mekansal Açıdan İncelenmesi: Ankara- Antalya Örneği.” Tekirdağ Ziraat Fakültesi Dergisi. 13/02. (2016): 85-95.

Tomkinson, G., Leger, A., Olds, T., Cazorla, G., "Secular Trends in the Performance of Children and Adolescents (1980-2000): an Analysis of 55 Studies of the 20 m Shuttle Run test in 11 Countries." Sports Medicine 33 (4), (2003): 285-300.

Topgül Ç, Elibol G.C. "Kurum Bakimi Altındaki 0-6 Yaş Çocukların Yaşama Mekânlarının Ev Kazaları Açısından İncelenmesi.” Journal of Society \& Social Work. 30/1, (2019):121-146.

Wilks, J. "Child-friendly Cities: a Place for Active Citizenship in Geographical and Environmental Education." International Research in Geographical and Environmental Education. Vol. 19, No. 1, February(2010): 25-38.

Wolfgang, C. H. Children Guidance Through Play: Teaching Positive Social Behaviors (Ages 2-7). USA: Merrill, 2004.

Wyver, S., Tranter, P., Naughton, G., Little, H., Sandseter, E. B. H., \& Bundy, A. “Ten Ways to Restrict Children's 
Freedom to Play: The Problem of Surplus Safety.” Contemporary Issues in Early Childhood, 11/3 (2010): 263277.

\section{Interner references}

Link 1. Ragan, D. \& McNulty, L. The Youth Friendly City: A Discussion Paper in Preparation for the World Urban Forum 2006, Environmental Youth Alliance, and the International Institute for Child Rights and Development. Available at http://www.scribd.com/doc/57052322/Youth-Friendly-CityEnglishversion

Link 2. http://en.besiktas.bel.tr/category/newcomers-guide/ 